\title{
MEMOIRS
}

\section{PROFESSOR KARL PEARSON}

IT is not usual for pages of the fournal to contain an account of men, however distinguished, who were not members of our profession, but it is true to say that no business and no profession is advanced without help from those who stand outside it, and in many walks of life the debt owed to laymen is greater than that owed to many who are more closely connected with the particular work. So far as modern actuarial work is concerned it owes much to Karl Pearson. It is pleasant to recall that he was an Honorary Member of the Actuaries' Club, and. much appreciating his election he dedicated one of his pamphlets on interpolation to "My Fellow-Members of the Actuaries' Club".

He was born in London in 1857 , educated at University College School and then King's College, Cambridge, where he was third Wrangler, and Fellow of his College. From Cambridge he went to Germany and, as he put it himself, studied physics and metaphysics at Heidelberg and Roman law and biology at Berlin. In I 882 he was called to the bar of the Inner Temple with the idea of following his father as a lawyer, but other interests intervened and not long after W. K. Clifford's death he was appointed to the Chair of Applied Mathematics and Mechanics at University College, London. There he did a lot of work on elasticity, strength of bridges, etc., and developed an interest in statistical work and in the application of mathematics to biological problems; later he became the first Galton professor of Eugenics, a post which he held until 1933 when he still continued to work at the College and look after publications from a room which was provided for him there. In 1935 his health definitely began to fail but he worked on, and a few days before his death on 27 April, he corrected some proofs for Biometrika, the periodical which he had been largely instrumental in starting in I900. After his death a letter typical of him was found on his blotting pad and published in The Times.

From our point of view it is natural to think of Karl Pearson mainly in respect of his statistical researches and what was to some extent the creation of a new subject; there is no member of our profession to-day who is not aware of Pearson's system of frequency curves, his method of fitting curves by the use of moments, his treatment of correlation and contingency, and his $\chi^{2}$ test originally devised by him to see whether a series of observations followed a presumed law or if a graduation was sufficiently near to the statistics on which it was based. Pearson's statistical work went far beyond this, and a glance at the titles of his papers will show that he left untouched little of importance in the 
application of mathematics to statistics. Other writers developed his work, and the $\chi^{2}$ method, for instance, has been developed for other purposes besides those for which it was invented. Pearson's application of the theoretical developments of the subject extended over such things as barometric pressures, anthropological measures, biology and latterly craniometry, in which he invented a new technique.

It is not exaggeration to say that there has never yet lived a man who has done more to advance the application of mathematical work to statistical analysis than Pearson. There are many who have written on the mathematics of the subject and many who have done excellent statistical work, but I can think of no one else who has had in combination his vision to move things forward, then the mathematical ability to express his ideas and finally his appreciation that the ultimate test must lie in the statistical applicability. I do not pretend for a moment that all his mathematical work or his statistical applications are even now acceptable but rather that his work has been so fundamentally important that the criticism and modification of it has been and will be due directly and indirectly to his own work-that perhaps is the best praise that can be paid to achievement.

Pearson's activities were not confined to his mathematical work, and to many people his The Grammar of Science probably counts for more than anything else he wrote. Anyone who wishes to appreciate Pearson's versatility should read that book again, then turn to his Ethic of Freethought, including among the historical essays one (The Kingdom of God in Munster) which to my taste is more vivid than anything else I know; he can go on to look at two volumes entitled The Chances of Death containing with much else studies of folk-lore, and when he comes to the life of Galton, he will be surprised not only at Galton's width of interest, but at Pearson's apparently intimate knowledge of many subjects presumably far outside his ordinary range. And even then what many would regard as a sufficient output for one man's life will remain unstudied.

Pearson was an inspiring teacher and induced enthusiasm in those who worked with him; he had not only the capacity of hard work himself but of obtaining it from others. He was wholeheartedly generous to a pupil or associate and would help him to make full use of any new idea. He was tenacious of his own views; and a keen controversialist who, I think, loved a fight. When in controversy he was willing to deal hard (in my view unnecessarily hard) blows, and he expected no quarter in return, but he would fight hardest when an attack had been levelled at the work of a pupil or at the joint work done by himself and someone else. Personally I always regretted his eagerness for controversy, but I am sure he indulged it because he believed that it was a way of finding out the truth; and it was the same underlying anxiety for what he thought was the truth that led him when editing papers for Biometrika 
to add notes of criticism or explanation which were not always appreciated by the authors. Consequently Pearson was not universally liked, and looking back I can see how easily people could misunderstand him; but though some did not like him, perhaps they were afraid of him; he was to most of those who came under his influence a man loved and revered who gave in ideas and inspiration something of immeasurable wealth.

W.P.E.

\section{FREDERICK SCHOOLING}

By the death of Mr Frederick Schooling, at the age of 84 , the profession loses a member who has been actively connected with life assurance for nearly 70 years.

Born in $185 \mathrm{r}, \mathrm{Mr}$ Schooling joined the staff of the Prudential Assurance Co. in 1867. He was appointed Actuary to the Company in 1892 and on retirement from this position, in 1912 , was elected a member of the Board of Directors. In I 928 he became Deputy Chairman, which position he retained until his death.

In 1886 he became a Fellow of the Institute of Actuaries. He took an active part in the affairs of the Institute and held successively the positions of Examiner, Honorary Secretary, Vice-President and President. He served on the Council for 18 years and was President from I9I2 to I9I4.

Mr Schooling contributed several papers to the Institute and to International Congresses. Among these was a paper written in collaboration with Mr E. A. Rusher on "The Mortality Experience of the Imperial Forces during the War in South Africa", which aroused considerable interest, and another on "Some Methods of grouping policies for the purpose of Valuation". This latter has for many years been regarded as a standard paper on the subject of Industrial Assurance Valuation.

In Igr I, when the first National Health Insurance Bill was before Parliament, $\mathrm{Mr}$ Schooling was one of those chosen to attend upon the Chancellor of the Exchequer to represent the Industrial Assurance Companies in their claim to take part in the administration of National Health Insurance.

$\mathrm{Mr}$ Schooling was also a member of the Council of the Royal National Pension Fund for Nurses and took a keen interest in a number of other associations connected with the welfare of the nursing profession.

A man of great versatility, in his younger days he took an active part in various forms of sport, a lively interest in which he maintained until the end. The close of a very full life will leave a gap in all those spheres of activity in which he was engaged and he will be missed by many who found in him a source of inspiration and encouragement.

W, E. HUSTWITT 